This document was prepared in conjunction with work accomplished under Contract No. DE-AC09-96SR18500 with the U. S. Department of Energy.

\title{
DISCLAIMER
}

This report was prepared as an account of work sponsored by an agency of the United States Government. Neither the United States Government nor any agency thereof, nor any of their employees, nor any of their contractors, subcontractors or their employees, makes any warranty, express or implied, or assumes any legal liability or responsibility for the accuracy, completeness, or any third party's use or the results of such use of any information, apparatus, product, or process disclosed, or represents that its use would not infringe privately owned rights. Reference herein to any specific commercial product, process, or service by trade name, trademark, manufacturer, or otherwise, does not necessarily constitute or imply its endorsement, recommendation, or favoring by the United States Government or any agency thereof or its contractors or subcontractors. The views and opinions of authors expressed herein do not necessarily state or reflect those of the United States Government or any agency thereof. 
Key Words:

Environment

Remediation

Chlorinated Solvents

Retention:

Permanent

\title{
SUMMARY OF IDENTIFICATION OF REGULATORY ACCEPTABILITY OF ENHANCED ATTENUATION CATEGORIES
}

\author{
UNCLASSIFIED \\ DOES NOT CONTAIN \\ UNCLASSIFIED CONTROLLED \\ ADC \& \\ Reviewing \\ Official: \\ (Name and Title) \\ Date:
}

\section{JANUARY 2006}

Westinghouse Savannah River Company Savannah River Site

Aiken, SC 29808

Prepared for the U.S. Department of Energy Under Contract Number DEAC09-96-SR18500
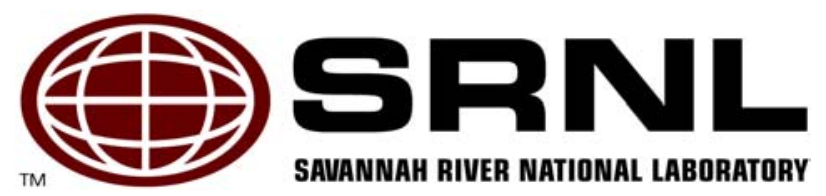


\section{DISCLAIMER}

Preparation of this report was coordinated by Westinghouse Savannah River Company (WSRC) for the United States Department of Energy (US DOE) under Contract No. DE-AC09-96SR18500. Extensive effort was made by the authors to assure the accuracy of the contents and interpretation. However, the USDOE nor WSRC, nor any of their employees makes any warranty, expressed or implied, or assumes any legal liability or responsibility for accuracy, completeness, or usefulness, of any information, apparatus, or product or process disclosed herein or represents that its use will not infringe privately owned rights. Reference herein to any specific commercial product, process, or service by trade name, trademark, name, manufacturer or otherwise does not necessarily constitute or imply endorsement, recommendation, or favoring of same by Westinghouse Savannah River Company or by the United States Government or any agency thereof. The views and opinions of the authors expressed herein do not necessarily state or reflect those of the United States Government or any agency thereof.

Printed in the United States of America

Prepared For

U.S. Department of Energy 
Key Words:

Environment

Remediation

Chlorinated Solvents

Retention:

Permanent

\title{
SUMMARY OF IDENTIFICATION OF REGULATORY ACCEPTABILITY OF ENHANCED ATTENUATION CATEGORIES
}

\author{
Prepared by the Karen Vangelas
}

\section{JANUARY 2006}

Westinghouse Savannah River Company Savannah River Site

Aiken, SC 29808
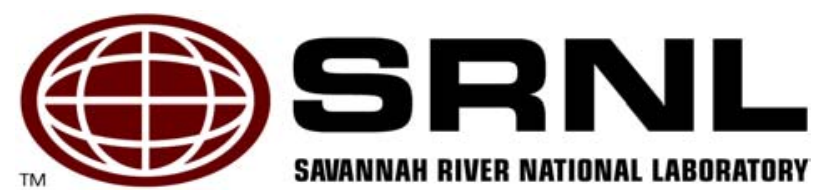
WSRC-TR-2005-00198, Rev. 0

January 4, 2006

Page 1 of 13

\section{INTRODUCTION}

Chlorinated solvents once introduced to the subsurface are a persistent contaminant. Though many types of active treatments have been developed and deployed to treat contaminated sites, most sites will ultimately incorporate the use of passive treatments into the remediation process. A process favored by many is the use of Monitored Natural Attenuation that relies on the natural attenuation processes occurring within the system to remediate the contaminants. However, it is likely there will be instances where the natural attenuation processes will be insufficient to reduce the level of contamination to acceptable levels in an acceptable span of time. Rather than redeploying source treatments, the Department of Energy along with the Interstate Technology and Regulatory Council (ITRC) are developing the concept of Enhanced Attenuation (EA). An enhancement is any type of intervention that might be implemented in a source-plume system that increases the magnitude of attenuation by natural processes beyond that which occurs without intervention. Enhanced Attenuation is the result of applying an enhancement or intervention technique that will sustainably manipulate a natural attenuation process leading to an increased reduction in mass flux of contaminants. Efforts are moving forward along several fronts in developing this concept. This effort is a follow-on to initial discussions with site owners, regulators and stakeholder organizations in the development of the concepts of Enhanced Attenuation, the use of mass balance to evaluate the stability of a waste site/groundwater plume, and identification of tools that will support characterization and monitoring efforts for MNA and EA treatments. Those discussions are documented in the report titled "Summary Document of Workshops for Hanford, Oak Ridge and Savannah River Site as part of the Monitored Natural Attenuation and Enhanced Passive Remediation for Chlorinated Solvents - DOE Alternative Project for Technology Acceleration (WSRC, 2003).

\section{OBJECTIVE}

The objective of this report is to document the May $12^{\text {th }}, 2005$ deliberations of the ITRC Enhanced Attenuation: Chlorinated Organics team. The purpose of these deliberations was to identify issues related to regulatory acceptability of the different categories of processes/technologies that may be considered enhancements.

\section{ORGANIZATION}

This report provides the summary slides of those deliberations. The first three slides provide general comments on implementing these categories of processes/technologies as enhancements. The remaining slides provide comments on individual classes of processes/technologies. These slides are presented in the following format: 
WSRC-TR-2005-00198, Rev. 0

January 4, 2006

Page 2 of 13

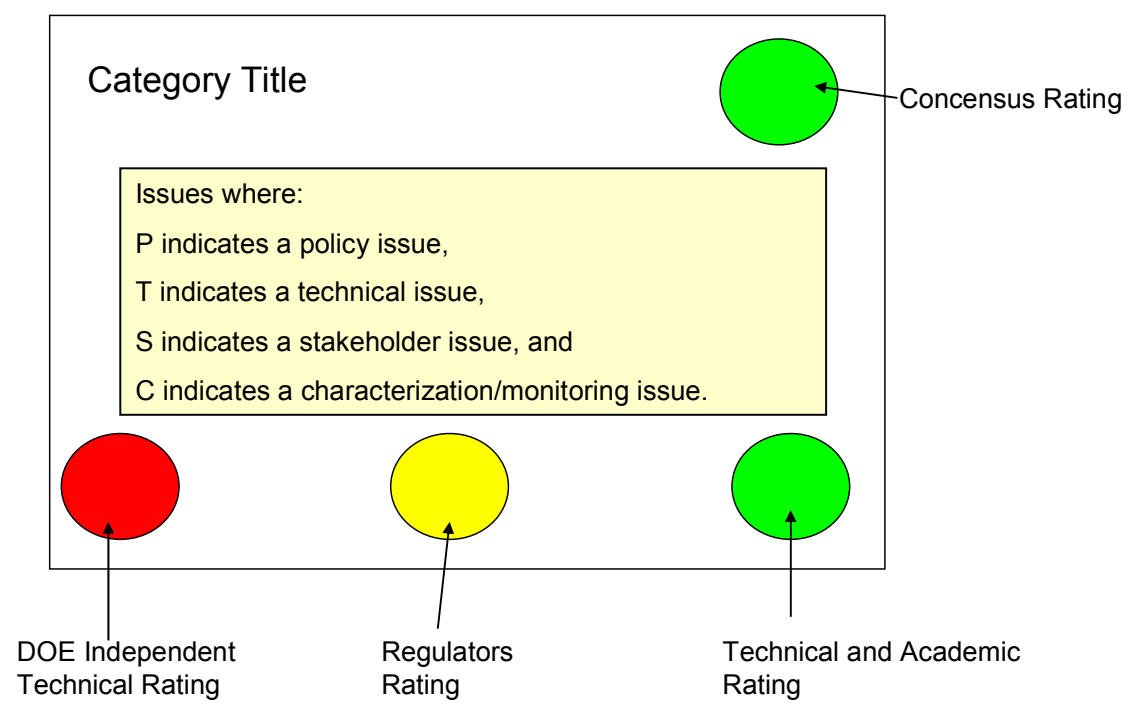

DOE Independent Technical Rating: During the initial development of EA and the categories of processes/technologies, the technical team leading the project for DOE identified, based on their own experiences, what they thought the regulator acceptability of each category would be.

Regulators Rating: During the May 12, 2005 meeting of the ITRC EACO team, a breakout session comprised of the state regulators on the team identified issues with each category and then provided a rating for each category.

Technical and Academic Rating: During the May 12, 2005 meeting of the ITRC EACO team, those members of the team that are not regulators but represent industry and academia met in a separate breakout session where they also identified issues with each category and then provided a rating for each category.

Concensus Rating: This rating is a culmination of the three ratings described above. This concensus rating was agreed to by all parties present at the May 12, 2005 meeting.

Ratings: There are three color coded ratings. More than one rating could be provided by any of the rating groups. An example reason for multiple ratings, is that there may be differing policies related to a single category across the states or even across different programs in a single state.

Issues: These are issues that were identified by more than one group or that one group identified as very important. 
WSRC-TR-2005-00198, Rev. 0

January 4, 2006

Page 3 of 13

Rating Code:

Green circle with center removed: Supportive

Yellow circle: Moderately Supportive

Red circle: Not Supportive

Participants in the breakout sessions were:

Naji Akladiss, Maine Department of Environmental Protection

Chris Benedict, Washoe County Department of Water Resources, Nevada

Robert Borden, North Carolina State University

Grant Carey, Conestoga-Rovers and Associates

John Doyon, New Jersey, Department of Environmental Protection

Rick Gillespie, Regenesis Bioremediation Products

Dennis Green, Stakeholder

Judie Kean, Florida Department of Environmental Protection

Raymond Knox, Schnabel Engineering Associates, LLC

Richard Lewis, HSA Engineers \& Scientists

Rick McGregor, XCG Consultants Ltd

Patrick McLoughlin, Microseeps, Inc.

Alec Naugle, California Regional Water Quality Control Board

Eric Nuttal, University of New Mexico

Kimberly Wilson, South Carolina Department of Health and Environmental Control

Ryan Wymore, Parsons

Fuxing Zhou, Virginia Department of Environmental Quality 
WSRC-TR-2005-00198, Rev. 0

January 4, 2006

Page 4 of 13

Summary Slides from Breakout Sessions on Enhanced Attenuation Categories 
WSRC-TR-2005-00198, Rev. 0

January 4, 2006

Page 5 of 13

\section{General Comments (examples)}

- All of the listed technologies will "work" in some cases. Key issues in assessing regulatory acceptability for all of the technologies will be an impression of how effective the technology will be and any potential risks or collateral damage they may cause. Need to minimize overall risk. Also need to emphasize robustness and sustainability.

- The consensus process is to

- 1) apply active remedy (never MNA) to the source zone (e.g., excavation, chemical oxidation or reduction, bioremediation and/or barrier).

- 2) apply active treatments to other portions of the plume as necessary, and

- 3) THEN can apply EA to that source and any other portion of the plume.

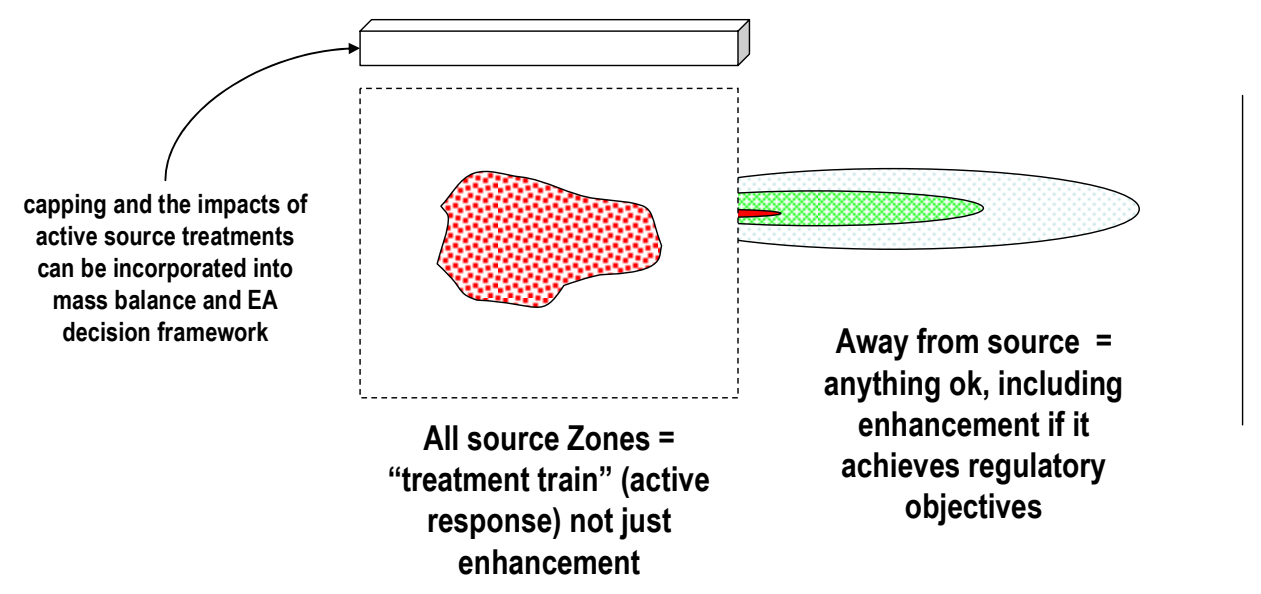

CONSENSUS REGULATORY POLICY PHILOSOPHY 


\section{For all technologies that reduce loading}

- Do not remove or destroy contaminant. When applied to the source zone they are not consistent with the general regulatory policy to remove or treat the source to the extent possible. These methods may:

- increase time frame

- result in secondary effects (e.g., reduced natural microbial activity)

- This reduces somewhat the regulatory acceptability of all of the methods in this category

\section{REDUCE INFILTRATION AT SOURCE}

- $P$ - For general use, capping is available and feasible. It is permitted "all the time."

- P - Capping and slurry walls not a traditional cVOC treatment technology.
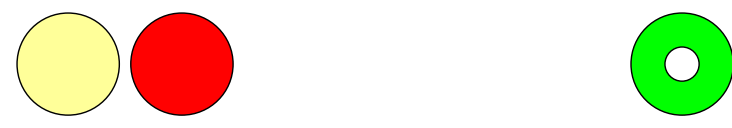


\section{Reduce Mass Transfer at Source (e.g. partitioning oil)}

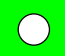

- T- Need to assure nontoxic and no toxic byproducts. Need to evaluate other collateral effects (e.g., gas generation, mineral precipitation, potential for mobilizing cVOCs)

- $\mathrm{P}$ - There may be issues or problems with putting in things that last a long time and are "irreversible." Technology limits future ability to remove contamination.

- T - Potential for coupling with destruction (oil will serve as e-donor) makes this uniquely attractive among the loading reduction technologies
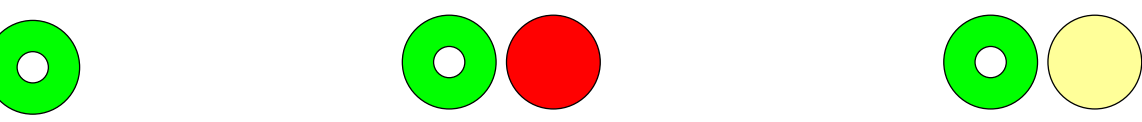

\section{Reduce Hydraulic Gradient}

reduce discharge upgradient or throughout the plume, engineered systems to remove clean water, trees for increased evapotranspiration

- T - Need to document sustainability and robustness.

- T - Probably will only be a component of a larger suite of technologies for a site (i.e., unlikely to be sufficient if used alone)

- $\mathrm{P}$ - OK - is done all the time
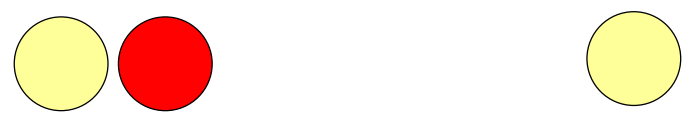


\section{Electron Acceptor Diversion}

- T - "Minimal record of case study", "Not implemented anywhere yet", "Immature Technology"

- C - Might need a large amount of data to justify design and performance

- T - Might be fighting natural geochemistry (e.g., rock as source of SO4) in some sites.

- P - Concept has merit and could be considered recommend follow up research (might let it be tried on a demo basis with contingency plan if does not work)
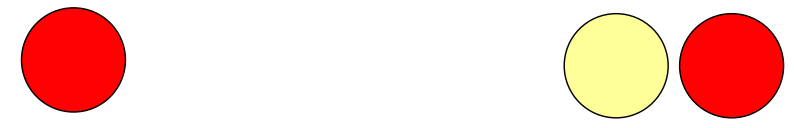

\section{Passive Vapor Extraction ("barometric pumping")}

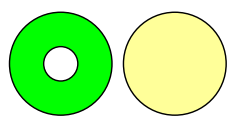

- $\mathrm{P}$ - typically in vadose zone AFTER active treatment (considered enhancement because it is passive low flow and it used for mass transfer limited release of residual)

- $\mathrm{P}$ - need to consider air releases and permitting in some states

- T - probably will only be a component of a larger suite of technologies for a site (i.e., unlikely to be sufficient if used alone)
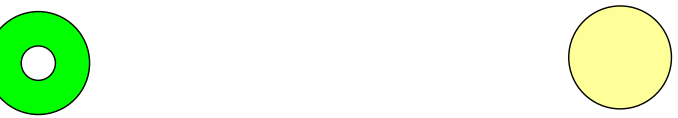


\section{DNAPL Drainage}

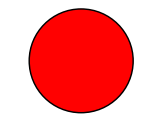

- $\mathrm{P}$ - Not really enhancement - it is an active removal like excavation or pump and treat

- T - likely to work only in unique situations - may work in fractures, but unlikely to work in silts or clays or in vadose zone.

- T - may not significantly reduce flux in the near term

- P - Regulatory policy may discourage moving DNAPL deeper (even in controlled situation).

- C - level of documentation and control would be extreme.

- T - lack of case studies and examples

\section{Biostimulation}

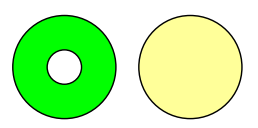

- S - concerned with secondary consequences and how long will it take.

- P - need more case studies

- T - sustainability

- T - may not address hot spots

- T - may form undesirable geochemical conditions and cause secondary water quality problems

- T - microbial dynamics and energetics need further study (i.e., are the organisms using the added carbon and nutrients for the desired degradation?)

- T - Need to consider collateral effects (e.g., anoxic conditions, mineral precipitation, gas formation, etc.)
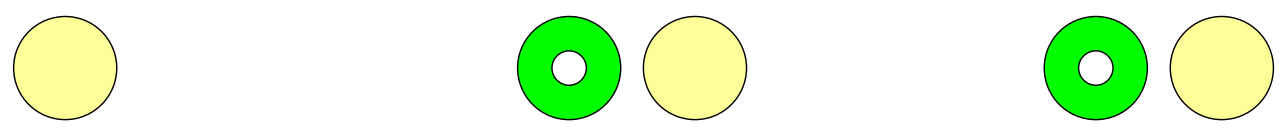


\section{Bioaugmentation}

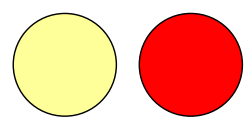

- Same as Biostimulation plus...

- $S$ - concerns about adding non-native organisms

- S - major concerns about genetically engineered organisms

- T - concerns about effect of non-native organism on cocontaminants (e.g., uptake of radionuclides)

- $\mathrm{S}-$ How is environment or ecosystem affected

- $\mathrm{C}$ - how do you measure the organisms (not just the contamination)

- T - Many case studies with some success being seen

- T - May not be necessary and may increase costs. May be difficult to implement on a large scale
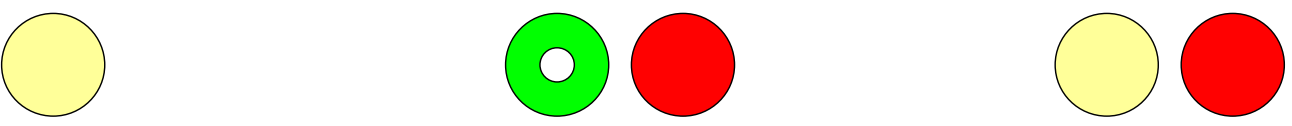

\section{Wetland Systems}

- T - May be complex and difficult to engineer

- C-May be difficult to measure specific performance mechanisms

- P - Significant uncertainty

- $S$ - Need to avoid ecological impacts

- P - may require significant maintenance

- T - constructed wetland provides more control and ability to understand/engineer processes, but still a complex system (but this also is a factor in potential robustness).

- P - Wetlands will be near stream or receptor. Many states view wetlands as surface water. Need to avoid violation of surface water standards. Constructed wetlands and submerged flow wetlands may be more acceptable.

- P -- ITRC has some treatment wetland guidelines (mostly for contaminant other than cVOCs)
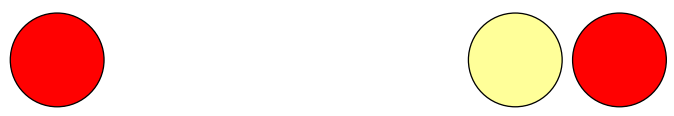


\section{Plant Based Methods}

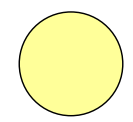

- T - air issues for phytoextraction (similar to barometric pumping)

- T - root zone degradation has high uncertainty and need much more development to be widely applicable - need information on robustness and sustainability under expected range of conditions.

- $S$ - non-natural species may cause adverse collateral damage (e.g., be invasive)

- C-difficult to monitor

- $\mathrm{P}$ - ITRC has guidance document on phytoremediation. Initial work was on metals (e.g., hyperaccumulators), but moved in to cVOCs. Breakdown of cVOCs has been documented.

- $P$ - Probably a niche treatment (rather than a general treatment that will address all site or even the bulk of contamination at any site).

- $S$ - Potential issues with food chain uptake
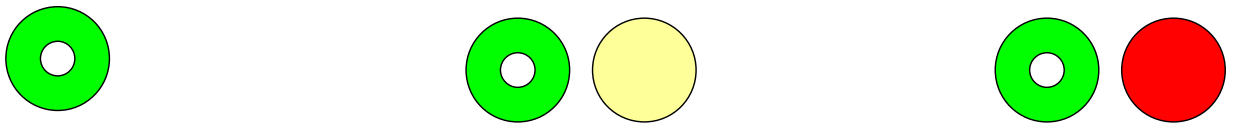

\section{Abiotic Geochmical Degradation}

- $T$ - Literature suggest that this is occurring naturally at some sites - but technology is "immature". May be difficult to enhance. May be applicable only to smaller plumes

- T - Enhancements (e.g., electron shuttles, nano-iron, etc) may cause secondary water quality effects.

- T - probably will not serve as a dominant mechanism at most sites - but might contribute to closure of mass balance

- T - sustainability
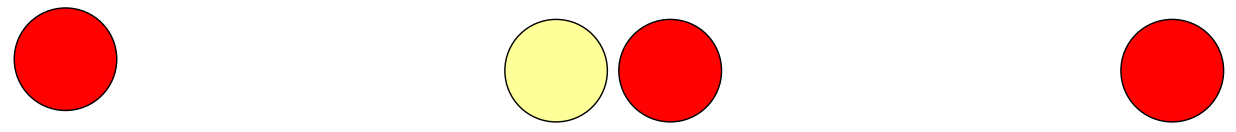


\section{Sustainable PRBs}

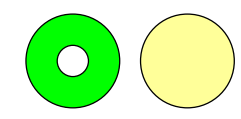

- T - sustainability

- T-mass balance concept may help provide design guidance and lifetime requirements

- T - Clogging of PRBs (e.g., for Fe based systems, issues of FeS in wall and $\mathrm{Fe}(\mathrm{II}) \rightarrow \mathrm{Fe}(\mathrm{III})$ in skin near wall, gas generation, etc.)

- T - organic based systems have not been fully proven (e.g, DCE formation but not destruction in some cases). Some systems (e.g., mulch) have "run out of gas".

- P - Might be difficult to design and prove as an EA - consider implementing as a PRB which has clear design guidance and regulatory track record. ITRC has team and many guidance documents.
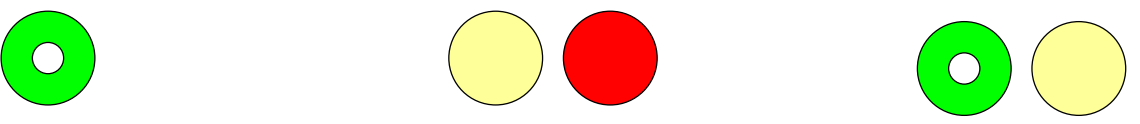

\section{Volatilization from Surface}

\section{Water}

- C-May be difficult to measure specific performance mechanisms

- $S$ - Need to avoid ecological impacts

- P -Need to avoid violation of surface water standards. Many state have policies that "do not allow plume to get in to surface water.

- T - Probably only for very low concentrations

- P - Not significantly different at low concentrations than an air stripper near stream

- T - Need to develop science because current policy is based on an arbitrary boundary rather than a technically based evaluation
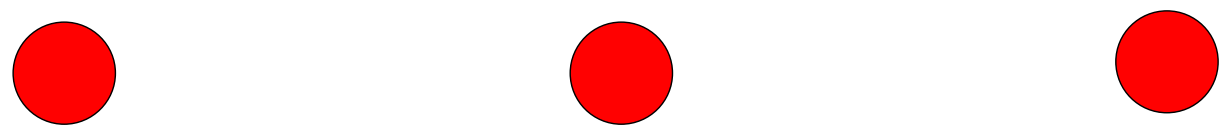
WSRC-TR-2005-00198, Rev. 0

January 4, 2006

Page 13 of 13

References:

WSRC, 2003. Summary Document of Workshops for Hanford, Oak Ridge and Savannah Rivers Sites as part of the Monitored Natural Attenuation and Enhanced Passive Remediation for

Chlorinated Solvents - DOE Alternative Project for Technology Acceleration. WSRC-RP-20031044, Rev. 0, October 20, 2003. U.S. Department of Energy Office of Environmental

Managements, available from the Office of Scientific and Technical Information, Oak Ridge TN. 